\title{
Invited Paper \\ Public health implications of meat production and consumption
}

\author{
Polly Walker ${ }^{1}$, Pamela Rhubart-Berg ${ }^{1}$, Shawn McKenzie ${ }^{1}$, Kristin Kelling $^{2}$ and \\ Robert S Lawrence ${ }^{1, *}$ \\ ${ }^{1}$ Center for a Livable Future, Johns Hopkins Bloomberg School of Public Health, 615 North Wolfe Street, W1033, \\ Baltimore, MD 21 205, USA: ${ }^{2}$ Department of International Health, Johns Hopkins Bloomberg School of Public Health, \\ Baltimore, MD, USA
}

\section{Submitted 31 January 2005: Accepted 2 March 2005}

\begin{abstract}
The high level of meat and saturated fat consumption in the USA and other highincome countries exceeds nutritional needs and contributes to high rates of chronic diseases such as cardiovascular disease, diabetes mellitus and some cancers. Affluent citizens in middle- and low-income countries are adopting similar high-meat diets and experiencing increased rates of these same chronic diseases. The industrial agricultural system, now the predominant form of agriculture in the USA and increasingly world-wide, has consequences for public health owing to its extensive use of fertilisers and pesticides, unsustainable use of resources and environmental pollution. In industrial animal production there are public health concerns surrounding feed formulations that include animal tissues, arsenic and antibiotics as well as occupational health risks and risks for nearby communities. It is of paramount importance for public health professionals to become aware of and involved in how our food is produced.
\end{abstract}

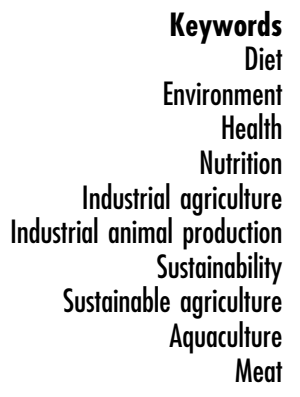

We live in a world of stark contradictions, where one billion people are overweight or obese and another one billion lack adequate food resources, despite the fact that current world food production could feed the 6.3 billion people on Earth if distributed equitably and based on a diet with only moderate amounts of animal products ${ }^{1,2}$. Food security experts question the capacity of the world's agricultural land to produce food sufficient to feed a growing world population, now expected to stabilise at about 9 billion in $2050^{3,4}$, in addition to providing adequate calories and improving dietary composition for the billion poorest in the world ${ }^{2}$. This problem is exacerbated by the loss of cropland to urban development, desertification, erosion and salinisation. In a world of increasing population, the fact that available cropland has decreased in the last 40 years from 0.5 to 0.23 hectares per capita is a serious reminder that agricultural production deserves more attention from policy-makers and public health professionals 5 .

Growing numbers of people world-wide are adopting energy-dense diets high in animal protein and fat $^{2}$. Although meat is not an essential component of the human diet, for the millions of people who are threatened with malnutrition, improving access to nutrient-rich animal source foods is an easy way to improve nutritional status. Animal products, however, are the primary source of saturated fat responsible for higher risk of cardiovascular disease, diabetes mellitus and some cancers. Meat itself is also associated with increased risk of some cancers ${ }^{6-12}$. An important public health challenge is to provide adequate amounts of protein and essential nutrients without also causing over-consumption of saturated fat.

Industrial methods of producing and processing animals for food within a vertically integrated industry (one corporate entity controls nearly every aspect of production and processing) is now well established in the USA for poultry, pork and beef. The increasing prevalence of these industrial methods in the USA and throughout the world, in part to satisfy a growing demand for meat, poses new public health threats. A high-meat diet also consumes many more resources than a plant-based diet. When grain supplies are fed to livestock rather than directly to humans, a significant amount of energy and resources is lost in converting grain calories to meat calories. More grain will be needed in the future just to meet the needs of an increasing population and to improve nutrition. In addition, it is estimated that global demand for meat will almost double by 2020, putting additional strain on limited resources and hampering our ability to feed the growing population $^{3}$. High-income nations feed over $60 \%$ of grain to livestock compared with low-income countries, where people consume most grain directly ${ }^{2,13}$. The proportion of 
grain fed to livestock is already increasing in many nations. For instance, grain fed to livestock increased by $31 \%$ in China and 63\% in Indonesia during the $1990 \mathrm{~s}^{3}$.

The present paper discusses the world-wide increases in consumption of industrially produced meat and other animal products, the related issues of growing grain for animal feed, and the public health implications of the accompanying transitions in agriculture and livestock production. While the discussion and data presented in the paper focus on the US experience, these same issues and problems are emerging globally as the industrial animal production (IAP) model is adopted and per capita meat consumption increases. Diets high in meat and animal products are resource-intensive and current IAP methods harm the health of the public and the environment ${ }^{14}$. Thus, dietary trends and food production methods are important issues for the public health community to address.

\section{Nutritional considerations of high-meat diets}

The US population typically consumes diets high in meat and saturated fat and low in fruits, vegetables and whole grains. This dietary pattern increases the risk for heart disease, certain types of cancer, stroke and diabetes - four of the leading causes of death in the USA. The costs due to poor diet for just these four diseases are estimated to exceed $\$ 33$ billion per annum ${ }^{15}$. On the other hand, high intakes of fruits, vegetables and whole grains and 'Mediterranean' dietary patterns, typically high in plantbased foods and unsaturated fats, lower the incidence of chronic diseases and their risk factors, including body mass index and obesity ${ }^{16-21}$.

Animal source foods provide a variety of important nutrients not easily obtained from plant foods, particularly lysine, bioavailable iron and zinc. Contrary to popular belief, the proteins from animal foods are only slightly superior in quality and utilisation than the proteins from plant foods ${ }^{22}$. Meat, however, can play a key role in preventing iron-deficiency anaemia, which is common in low-income countries and certain populations in middleand high-income countries. Small amounts of meat in the diet provide easily absorbable haem iron and also enhance iron absorption from plant foods ${ }^{22}$.

Meat and dairy foods contribute all of the cholesterol and the great majority of the saturated fat to the diet typical in the USA. Although dietary fats play an important role in a variety of biological functions, dietary saturated fats have no identified health benefits or minimum safe intake levels. The latest Dietary Reference Intakes for macronutrients recommend a saturated fat intake as low as possible while consuming a nutritionally adequate diet ${ }^{23}$. As societies develop economically, sources of dietary fat often change as animal food products replace some cereal and fibre intake $e^{14,24}$.
Meat is not a necessary component of a well-planned diet. Ovo-lacto vegetarian diets that include eggs and lowfat dairy products can easily be nutritionally adequate, and current research suggests that plant-based diets may lower the risk for chronic diseases ${ }^{25,26}$. One study suggests that diets high in animal protein, regardless of fat content, increase the risk of cardiovascular mortality ${ }^{27}$. The American Dietetic Association ${ }^{25}$ states, 'Vegetarian diets offer a number of nutritional benefits, including lower levels of saturated fat, cholesterol, and animal protein as well as higher levels of carbohydrates, fiber, magnesium, potassium, folate, and antioxidants such as vitamins $\mathrm{C}$ and $\mathrm{E}$ and phytochemicals. Vegetarians have been reported to have lower body mass indices than non-vegetarians, as well as lower rates of death from ischemic heart disease; vegetarians also show lower blood cholesterol levels; lower blood pressure; and lower rates of hypertension, type 2 diabetes, and prostate and colon cancer'.

Demand for meat in the USA continues to grow, particularly for poultry ${ }^{28,29}$ (see Fig. 1). The American Heart Association recommends an upper limit of $138 \mathrm{lb}$ $(62.6 \mathrm{~kg})$ of lean meat per person each year, more than $80 \mathrm{lb}(36.3 \mathrm{~kg})$ less than the current average US consumption of $222 \mathrm{lb}(100.7 \mathrm{~kg})^{30,31}$. Americans consume about 10 billion animals each year, not including fish, averaging, for a family of four, 120 chickens, four pigs and one $\operatorname{cow}^{32}$.

The average American derives $67 \%$ of dietary protein from animal sources, compared with a world-wide average of $34 \%^{33}$. While some high-income countries are attempting to improve dietary choices and curb excessive food consumption, middle- and low-income countries are adopting the food systems and diets of high-income countries $^{3,34}$. Annual global meat production is expected to increase from 218 million tons in 1997-1999 to 376 million tons by $2030^{35}$. In the poorest countries, especially in some regions of Africa where protein, iron and micronutrient deficiencies are most common, a moderate increase in meat and dairy food consumption will certainly improve the nutritional adequacy of diets (especially bioavailability of iron and lysine) and improve health outcomes $^{35}$. In addition, small-scale livestock production

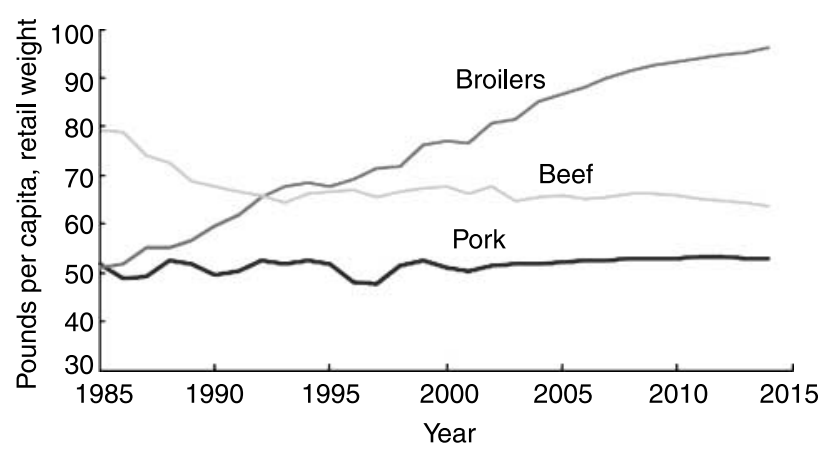

Fig. 1 Per capita meat consumption (source: USDA Agricultural Baseline Projection to 2014, February 2005. Economic Research Service, US Department of Agriculture) 
may help improve household food security and alleviate poverty. The Food and Agriculture Organization of the United Nations has found that village chicken production can help rural communities in Africa move from subsistence activities to more economically viable levels of production that benefit the community ${ }^{36}$.

There is much debate, however, about whether the current food production system will be able to meet the envisioned growth in meat consumption on a global scale irrespective of meeting the challenge of a more equitable - and healthier - distribution of animal products.

\section{The agriculture system and grain feed production}

Agriculture developed over 10000 years ago. Since World War II, traditional food production has been replaced by a system of industrial agriculture that relies on synthetic inputs such as chemical fertilisers and pesticides, extensive irrigation, fossil fuel, monocropping, harvest mechanisation and the development of high-yielding plant varieties. During the past half century, this industrial approach to agriculture has resulted in spectacular increases in productivity. For example, in 1999, US farmers produced about 134 bushels of corn per acre compared with only 30 in 1920, an increased yield of nearly $350 \%{ }^{33}$. But this tremendous increase in crop yields per acre comes at great cost to the health of the environment, workers and the public.

These costs are commonly referred to as 'externalities' because they are not included in either the retail price of the product or in analyses of the industry's productivity. Externalities of the industrial agriculture system include the depletion of resources such as fossil fuel, water, soil and biodiversity; pollution of the environment by the products of fuel combustion, pesticides and fertilisers; and economic costs to communities. A sustainable agricultural system will need to include these externalities when balancing inputs and outputs ${ }^{33,37}$. Government subsidies may also promote unsustainable use of resources. For instance, subsidies for water in arid areas promote agriculture requiring heavy irrigation, often at the cost of depleting fossil aquifers. Irrigation has transformed agriculture by increasing yields and extending cultivation to arid regions. Approximately two-thirds of water use world-wide is now devoted to irrigation ${ }^{38}$, but the current rate of water use for irrigation is unsustainable.

The Stockholm International Water Institute 2004 report, presented to the United Nations Commission on Sustainable Development, emphasised the direct relationship between the availability of water and the world's ability to meet the nutrition requirements of the population ${ }^{39}$. Throughout the world, aquifers are being depleted for irrigation faster than the hydrologic cycle can replenish them (e.g. the Ogallala aquifer in the US Midwest, and aquifers in the northern plain of China, the Punjab and the Middle East) ${ }^{14}$. Water is a vital resource, and therefore must be priced appropriately if rational, more efficient and sustainable practices are to be widely adopted in agriculture $^{37}$.

Industrial agriculture also relies heavily on chemical fertilisers, pesticides and herbicides. World-wide use of these chemical inputs has increased dramatically since World War II. Global agriculture uses 3 million tons of pesticides each year. Over 1600 chemicals are used in the manufacture of pesticides and most have not been tested for toxic effects on humans ${ }^{33}$. Agricultural runoff pollutes ground and surface waters with large amounts of nitrogen and phosphorus from fertilisers, pesticides and agricultural waste. According to the US Environmental Protection Agency (EPA) ${ }^{40}$ in congressional testimony, agriculture is the main source of pollution in US rivers: 'Based on ... reports from all 50 States, we [the EPA] estimate[s] that agriculture generates pollutants that degrade aquatic life or interfere with public use of 173,629 river miles (i.e. $25 \%$ of all river miles surveyed) and contributes to $70 \%$ of all water quality problems identified in rivers and streams'.

Pesticides pose many human health risks including acute poisoning, long-term effects on the immune, reproductive and nervous systems, and increased cancer risk $^{33}$. Exposure to these harmful chemicals can occur either by direct contact or by consuming contaminated food or water. Some pesticides 'bioaccumulate' in fatty tissues in a similar manner to dioxin, thereby increasing the risk from exposure (see Box $1^{41}$ ). Low- and middleincome countries bear an additional public health burden

\section{Box 1 - Relationship of environmental pollutants, animal feed and human health}

Persistent organic pollutants such as dioxins, furans and polychlorinated bromides enter the human food chain through the diets of food animals. The source of these organic compounds for food animals is contaminated forage and soils and the animal feed, which contains about $11 \times 10^{9} \mathrm{lb}\left(4.9 \times 10^{9} \mathrm{~kg}\right)$ of recycled animal fat per year in the USA. Once ingested, the dioxins and other compounds are absorbed and stored in the fat of the animal. By continually re-feeding fat from such animals back to other animals, the dioxins are concentrated more and more, a process called bioaccumulation. When humans consume animal fat in meat and dairy products, they are exposed to these pollutants that are carcinogenic and toxic to the developing nervous system of the foetus and to young children. The Institute of Medicine Dioxin Study Committee recommended that animal producers should, 'Reduce or eliminate the use of animal fats and oils, which may be high in DLCs [dioxin-like compounds], as ingredients in animal feeds'. Removing fat from animal feed would break this cycle and reduce dioxin levels in the food supply ${ }^{41}$. 
from the use of pesticides that have been banned for use, but not production, in the US and Europe.

\section{Overview of industrial animal production}

The industrialisation of grain production has produced yields sufficient in the short term to feed larger numbers of animals than could be raised sustainably on grass and traditional sources of forage. IAP methods produce large quantities of protein through an inefficient conversion of grain to protein. Cattle, for example, require $7 \mathrm{~kg}$ of grain to produce $1 \mathrm{~kg}$ of beef, whereas pigs require $4 \mathrm{~kg}$ of grain to produce $1 \mathrm{~kg}$ of pork, and poultry require only $2 \mathrm{~kg}$ of grain to produce $1 \mathrm{~kg}$ of poultry ${ }^{33,42}$. In addition, the amount of water required to produce protein by IAP includes both that which is consumed directly by the animals and the approximately 1000 tons of water needed to grow 1 ton of grain for feed ${ }^{43}$.

The industrial system of growing and processing large numbers of animals in heavy concentrations was first used in the 1930s and 1940s in the poultry industry. The beef cattle, pig, dairy and some aquaculture industries (see Box $2^{44-47}$ ) have now adopted industrial procedures. In IAP, animals grow to market weight in facilities known as concentrated animal feeding operations (CAFOs). The US EPA criteria for large CAFO designation are speciesspecific and indicate the minimum number of animals at the operation: large CAFOs are operations with more than 1000 cattle (or cow/calf pairs), more than 2500 swine (weighing over $55 \mathrm{lb}(25 \mathrm{~kg})$ ), and more than 125000 chickens not including laying hens ${ }^{48}$. CAFOs now dominate US livestock and poultry production. In the USA in 1966, 57 million pigs were distributed among one million farms; in 2001 these same 57 million pigs were raised on 80000 farms, and over half were raised in just 5000 facilities $^{49}$ (see Figs 2 and 3).

Vertical integration of the industry has occurred along with industrialisation of production systems and methods, with just a few corporations now dominating all animal production in the USA. Typically, one corporation owns and controls virtually all aspects of production - from formulating the feed, breeding the chicks or pigs and growing the animals to market weight, to processing ('meat packing') and shipping finished cuts of meat to market.

IAP impacts the environment and public health in many ways. The documented harmful health effects of CAFOs motivated the American Public Health Association in 2003 to adopt a resolution calling for a moratorium on the building of new CAFOs until additional data can be gathered and policies implemented to protect public health ${ }^{50}$.

\section{Public health impacts of industrial animal production}

In addition to producing large quantities of meat, CAFOs also contribute vast amounts of waste to the environment,

\section{Box 2 - Aquaculture}

Industrial production of fish (also called aquaculture or 'fish farming') is the newest application of industrial methods to producing animal protein and has increased rapidly during the past 30 years. The public health implications of the industrial methods used to grow aquatic species are similar to the public health implications of the industrial production of meat and poultry.

Aquaculture has expanded without consideration for the potential ecological effects such as habitat destruction, nutrient discharge and chemical pollution that may have consequences on other aquatic species as well as public health impacts ${ }^{44}$. The severity of these impacts depends on the type of system used for that particular species; for instance, open-ocean pens for salmon versus closed land-based tanks for catfish. Also, since it takes $2-5 \mathrm{lb}(0.9-2.3 \mathrm{~kg})$ of wild caught ocean fish to produce $1 \mathrm{lb} \quad(0.45 \mathrm{~kg})$ of farmed fish, aquaculture is contributing to the destruction of ocean fisheries ${ }^{44}$.

Consumers are faced with a dilemma in deciding which fish to include in their diets and how much. Many species of fish have high amounts of healthy omega-3 and omega-6 fatty acids. Carnivorous fish such as tuna, swordfish, mackerel and tile fish bioaccumulate persistent organic pollutants in their fatty tissue as they grow larger. Farmed fish, however, have higher concentrations of polychlorinated bromides and dioxin due to ingestion of formulated aquaculture feed. According to some researchers, wild fish species are less likely to have cancer-causing pollutants than farm-raised fish $^{45}$. Ingestion of methyl mercury in the tissues of these same fish species by pregnant women can cause neurotoxic effects in the developing foetus ${ }^{46}$. The US Food and Drug Administration and Environmental Protection Agency now discourage consumption of the above fish species by women of childbearing age, pregnant and nursing women and young children - all of whom are at greatest risk from mercury toxicity.

Despite these risks, many experts believe that for most adults the nutritional benefits of omega- 3 fatty acids outweigh the risk from pollutant exposure ${ }^{47}$.

including manure, urine, carcasses, excess feed and feathers. As of 1997, animals in the US IAP system produced a grand total of approximately 1.4 billion tons of waste. This is equivalent to about 5 tons of animal waste for each person in the USA ${ }^{33}$. For instance, since a pig produces about four times as much solid waste as an average person, a typical CAFO of 5000 pigs is equivalent to a small city of 20000 people with no sewage treatment plant ${ }^{51}$. 


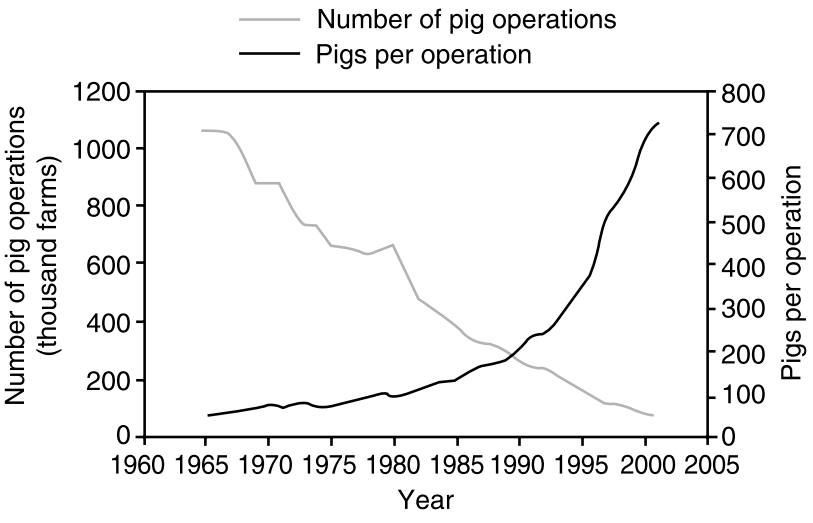

Fig. 2 Change in pig industry structure, 1965-2001 (source: US Department of Agriculture National Agriculture Statistics Service and US Census of Agriculture, various years)

Serious public health risks result ${ }^{33,52,53}$. CAFOs produce more waste than can be used on nearby fields as fertiliser. The waste is expensive to transport, and storage and disposal of CAFO waste is difficult because of the sheer volume produced. Storage pits for pig waste or poultry manure piles leak their contents into groundwater and streams and become even more problematic if sited in a flood plain or below the water table. Wastes from storage pits are subsequently spread or sprayed on land near the $\mathrm{CAFO}$, and this application can pollute the air and water ${ }^{54}$. Levels of phosphorus and nitrogen in the waste often exceed what the crops can utilise or the soil can retain. Excess nutrients contaminate surface waters and streams, causing eutrophication of nearby water bodies ${ }^{49,54}$. In addition to environmental impacts, CAFO waste creates many public health risks ${ }^{50,52}$. Central to these concerns is the fact that in addition to grains, animal feeds may also include animal wastes, animal tissues, animal by-products and other additives that end up contaminating human food or the environment. Many feed ingredients used in
CAFOs pass through the animal directly into manure, including heavy metals such as arsenic, antibiotics, nitrogen and phosphorus ${ }^{55-57}$. The manure also contains dust, mould, pathogenic bacteria and bacterial endotoxins ${ }^{50,58}$

The need for increased public health scrutiny of IAP animal feed composition was highlighted in 2003 when a cow in the US meat production system was found to have bovine spongiform encephalopathy (BSE or 'mad cow disease'). BSE is a transmissible, neurodegenerative, fatal disease of cattle with an incubation period of $4-5$ years. Animal feed that includes BSE-contaminated tissue (i.e. brain, spinal cord, etc.) is a prime way for the disease to spread.

Other CAFO public health threats include direct health risks to workers, consumers and the community in addition to indirect health risks mediated by environmental pathways. Figure 4 illustrates these relationships.

Antibiotics at sub-therapeutic levels, as well as arsenic and other metal compounds, are used in animal feeds to promote growth of the animals in IAP. The Union of Concerned Scientists estimates that more than $70 \%$ of all antibiotics produced in the USA are used in animal production. Many of these antibiotics are closely related to those used to treat infections in humans. Resistant strains of bacteria that develop in CAFO animals threaten the usefulness of these medicines in treating humans $^{59}$. In addition, 25-75\% of antibiotics pass unchanged from feed to manure and create risks to soil and water quality ${ }^{60}$. In 1997, the World Health Organization recommended the end of non-therapeutic use of antibiotics in animal husbandry because resistant strains of human pathogens had been identified ${ }^{61}$. In 2004 the American Public Health Association adopted Resolution 2004-13, 'Helping Preserve Antibiotic Effectiveness By Stimulating Demand For Meats Produced Without Excessive Antibiotics, 62 .

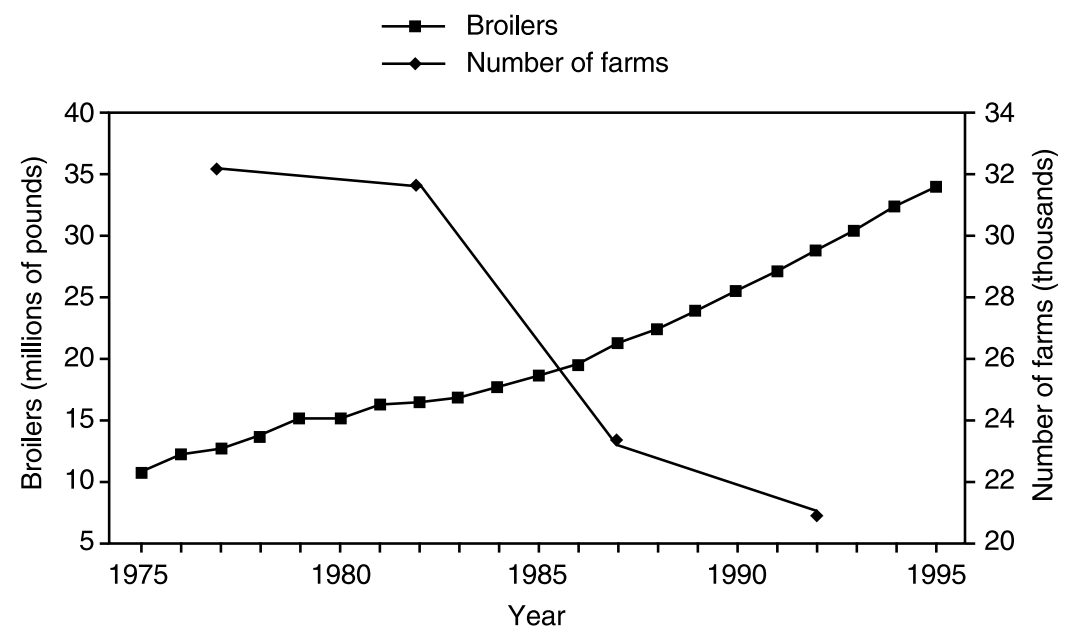

Fig. 3 Broiler production and number of farms in the USA, 1975-1995 (source: US Department of Agriculture National Agriculture Statistics Service and US Census of Agriculture, various years) 
Public health implications of meat production and consumption

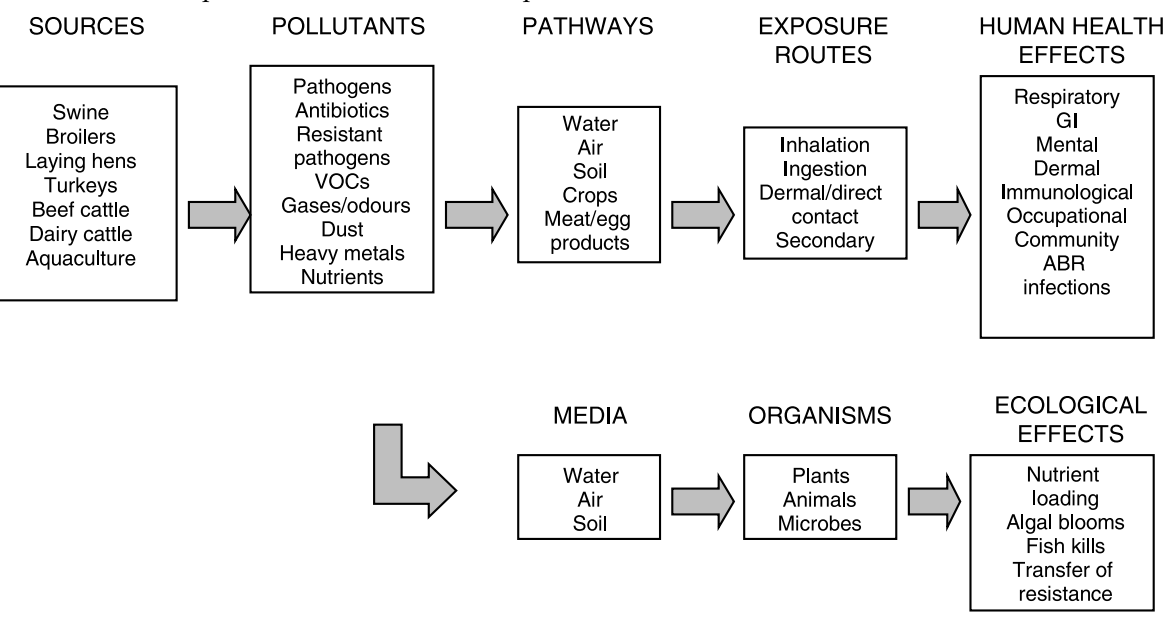

Fig. 4 Source-to-effect paradigm of concentrated animal feeding operations. VOCs - volatile organic compounds; GI - gastrointestinal; ABR - antibiotic-resistant organisms (kindly provided by Amy R Chapin, doctoral candidate, Department of Environmental Health Sciences, Johns Hopkins Bloomberg School of Public Health, Baltimore, MD, USA)

CAFO-generated wastes also contain pathogens that can cause disease in humans, including Salmonella, Campylobacter and Cryptosporidium, and can pollute drinking water with nitrates in concentrations potentially fatal to infants ${ }^{63}$. Organic dust, bacterial endotoxins and manure-generated compounds such as ammonia and hydrogen sulfide are also found in CAFO-generated wastes $^{64}$. Many of the exposures to pollutants from IAP operations are intensified for employees and the people living in the surrounding communities. Air polluted with ammonia, sulfur dioxide and dust from CAFOs is harming the health of both workers and residents living downwind from these operations. Published studies have documented a variety of contaminants, microbial agents and health effects in workers exposed to swine $e^{52,53,65-67}$. These studies provide the groundwork for an increasing body of research to evaluate possible community health effects. Just as second-hand smoke affects not just the smoker but also impacts the health of those nearby, the process of producing cheap meat can cause health effects not only for workers but also for their families and local community members.

As many as $30 \%$ of CAFO workers suffer from occupational respiratory diseases such as acute and chronic asthma ${ }^{33}$. In addition, CAFO workers experience numerous occupational health hazards from manure gases, odours and degradation products; bacteria; endotoxins; and dust ${ }^{49}$. Current studies are measuring the extent to which poultry workers have antibioticresistant strains of bacteria in their systems, develop clinical infections, or become carriers for infections via direct contact with diseased animals or breathing CAFO air. Workers in IAP processing plants also suffer high rates of worker injury and repetitive motion syndrome, and report a lack of proper protective equipment ${ }^{68,69}$. These workers lack adequate health benefits, and the cost of their occupational health problems is not reflected in the current pricing of meat for the consumer.
Residents in rural communities are generally excluded from decisions to build new CAFOs, but they often suffer serious consequences such as diminished quality of life, reduction in property values, the presence of unbearable odours and contaminated wells once CAFOs arrive ${ }^{58,70}$. Community members and children of CAFO operators are also exposed to pollutants from CAFOs. A University of Iowa study found that people living near large-scale pig facilities reported higher incidence of headaches, respiratory problems, eye irritation, nausea, weakness, and chest tightness $^{71}$. Children of CAFO operators in Iowa have higher rates of asthma than do other farm children ${ }^{67}$. Three studies have documented increased rates of physical and mental illness among people living near $\mathrm{CAFOs}^{52}$. Additional studies are needed to assess the full health effects of different forms of pollution, noise levels and odours on nearby residents. These social and health costs are also 'externalised' from the pricing system for cheap meat.

\section{Conclusion}

The public health implications of the industrial agricultural system, and in particular IAP, are becoming clearer each year. The direct health effects on workers, community members and consumers from chemical pesticides and fertilisers, antibiotic-resistant organisms, respiratory irritants and work-related injuries are increasingly attributed to IAP. Indirect environmental effects also have farreaching implications. Unsustainable IAP use of resources includes degradation and loss of soil, consumption of fossil fuels and extraction of water from fossil aquifers. In addition, pollution of land, streams and underground water supplies with agricultural pesticides and fertilisers and with arsenic and other heavy metals from animal feed are environmental problems that will affect public health both now and well into the future. As biologist EO Wilson 
says: 'The key problem facing humanity in the coming century is how to bring a better quality of life - for 8 billion or more people - without wrecking the environment entirely in the attempt ${ }^{72}$.

The IAP system has grown along with the increase in average meat consumption by people living in highincome nations, particularly the USA. The system provides artificially cheap meat for the consumer, and consumer demand in turn fuels the IAP system. The amount of meat and saturated fat consumed exceeds nutritional needs and is responsible for increased rates of heart disease, stroke and some cancers. In addition, demand for animal foods will continue to increase world-wide as the population grows and rising incomes allow the adoption by urban élites everywhere of the high-meat/high-fat diet now typical in the USA. At the same time, nearly one billion people in the world lack sufficient food to meet basic nutritional needs ${ }^{73}$, in sharp contrast to the one billion in the world, mostly in high-income nations, who are overweight or obese.

Public health professionals have many opportunities to bring about change. The following actions would begin to address the health and environmental hazards of IAP.

1. Maximise incentives for sustainable agricultural techniques that take into account local ecology and strive to achieve no net loss of topsoil, soil productivity, biological diversity, water and other resources. These would include mandatory nutrient management plans for agricultural land, pricing to regulate water use, and decreasing subsidies for the production of grain.

2. Curb the current increase in high-meat diets worldwide by changing policies to encourage diets lower in meat and saturated fat and higher in vegetable, fruits and grains. The US Department of Agriculture (USDA) Dietary Guidelines $2005^{74}$ are an important step toward policies to improve human health and indirectly - agricultural practices.

3. Create a regulatory framework that captures the externalities of current meat production in the USA and includes these costs in the price of meat (e.g. the true cost of growing grain).

4. End commodity agricultural subsidies in the USA to increase the ability of poor farmers in low- and middleincome countries to develop a viable agricultural sector. Adding incentives for farmers to grow more healthful choices of fruits and vegetables would provide a more balanced system.

5. Improve the poor wages in the farm sector, another factor that keeps the cost of meat artificially low in the USA. If the workers in the meat industry (growers, slaughterhouse workers, catchers, line workers) all received adequate wages and benefits and safe working conditions were enforced, the price of meat would increase. In addition, an appropriate USDA inspection force would need to be funded by taxing the industry.

6. Strengthening the bridge between public health and the agriculture communities is necessary to address the environmental and health effects and unsustainable resource use of IAP. Establishing an agricultural section at the American Public Health Association would be one indication that public health has reclaimed food production as a very important area of concern for the health of the public now and in the future. Only then will we be able to change Wendell Berry's observation $^{75}$ that, "There is no connection between food and health. People are fed by the food industry, which pays no attention to health, and are healed by the health industry, which pays no attention to food'.

Public health professionals - especially those with expertise in human nutrition - should lead in making the connection between food and the health of the public, the health of the food system, and the health of the ecosystem.

\section{References}

1 Kendall HW, Arrow KJ, Borlaug NE, Ehrlich PR, Lederberg J, Vargas JI, et al. Meeting the Challenges of Population, Environment, and Resources: The Cost of Inaction, Washington, DC: World Bank, 1996.

2 Smil V. Food production. In: Caballero B, Popkin BM, eds. The Nutrition Transition: Diet and Disease in the Developing World, New York, NY: 1st ed. San Diego, CA: Academic Press, 2002; 25-50.

3 Myers N, Kent J. New consumers: the influence of affluence on the environment. Proceedings of the National Academy of Sciences of the USA 2003; 100(8): 4963-8.

4 United Nations (UN). World Population to 2300. ST/ESA/ SER.A/236. New York, NY: UN, 2004.

5 Pimentel D, Wilson A. World population, agriculture and malnutrition. WorldWatch 2004; (September/October): $22-5$.

6 Mann JI. Diet and risk of coronary heart disease and type 2 diabetes. Lancet 2002; 360(9335): 783-9.

7 Key TJ, Schatzkin A, Willett WC, Allen NE, Spencer EA, Travis RC. Diet, nutrition and the prevention of cancer. Public Health Nutrition 2004; 7(1A): 187-200.

8 Hu FB, Willett WC. Optimal diets for prevention of coronary heart disease. Journal of the American Medical Association 2002; 288(20): 2569-78.

9 Chao A, Thun MJ, Connell CJ, McCullough ML, Jacobs EJ, Flanders WD, et al. Meat consumption and risk of colorectal cancer. Journal of the American Medical Association 2005; 293(2): 172-82.

10 Van Horn L. Fiber, lipids, and coronary heart disease. A statement for healthcare professionals from the Nutrition Committee, American Heart Association. Circulation 1997; 95(12): 2701-4.

11 van Dam RM, Rimm EB, Willett WC, Stampfer MJ, Hu FB. Dietary patterns and risk for type 2 diabetes mellitus in US men. Annals of Internal Medicine 2002; 136(3): 201-9.

12 Fung TT, Schulze M, Manson JE, Willett WC, Hu FB. Dietary patterns, meat intake, and the risk of type 2 diabetes in women. Archives of Internal Medicine 2004; 164(20): $2235-40$. 
13 Speedy AW. Global production and consumption of animal source foods. Journal of Nutrition 2003; 133(Suppl.): 4048S-53S.

14 McMichael A. Planetary Overload: Global Environmental Change and the Health of the Human Species. Cambridge: Cambridge University Press, 1993.

15 Frazao E. High costs of poor eating patterns in the United States. In: Frazao E, ed. America's Eating Habits: Changes and Consequences. Agriculture Information Bulletin No. 750. Washington, DC: Economic Research Service, US Department of Agriculture, 1999; 5-32.

16 Schroder H, Marrugat J, Vila J, Covas MI, Elosua R. Adherence to the traditional Mediterranean diet is inversely associated with body mass index and obesity in a Spanish population. Journal of Nutrition 2004; 134(12):3355-61.

17 Produce for Better Health Foundation. State of the Plate Research Report 2002. Wilmington, DE: Produce for Better Health Foundation, 2002.

18 Liu S, Willett WC, Manson JE, Hu FB, Rosner B, Colditz G. Relation between changes in intakes of dietary fiber and grain products and changes in weight and development of obesity among middle-aged women. American Journal of Clinical Nutrition 2003; 78(5): 920-7.

19 Panagiotakos DB, Pitsavos C, Chrysohoou C, Stefanadis C, Toutouzas P. Primary prevention of acute coronary events through the adoption of a Mediterranean-style diet. Eastern Mediterranean Health Journal 2002; 8(4-5): 593-602.

20 Davis MS, Miller CK, Mitchell DC. More favorable dietary patterns are associated with lower glycemic load in older adults. Journal of the American Dietetic Association 2004; 104(12): 1828-35.

$21 \mathrm{Hu}$ FB, Willett WC. Optimal diets for prevention of coronary heart disease. Journal of the American Medical Association 2002; 288(20): 2569-78

22 Bender A. Meat and Meat Products in Human Nutrition in the Developing World. Food and Nutrition paper No. 53. Rome: Food and Agriculture organization of the United Nations, 1992; 53.

23 National Research Council. Dietary Reference Intakes for Energy, Carbohydrates, Fiber, Fat, Protein, and Amino Acids (Macronutrients). Washington, DC: National Academies Press, 2003.

24 Popkin BM, Du S. Dynamics of the nutrition transition toward the animal foods sector in China and its implications: a worried perspective. Journal of Nutrition 2003; 133(Suppl. 2): 3898S-906S.

25 American Dietetic Association. Vegetarian diets - position of the American Dietetic Association. Journal of the American Dietetic Association 1997; 97: 1317-21.

26 Singh PN, Sabate J, Fraser GE. Does low meat consumption increase life expectancy in humans? American Journal of Clinical Nutrition 2003; 78(Suppl. 3): 526S-32S.

27 Kelemen LE, Kushi LH, Jacobs DR Jr, Cerhan JR. Associations of dietary protein with disease and mortality in a prospective study of postmenopausal women. American Journal of Epidemiology 2005; 161(3): 239-49.

28 US Department of Agriculture. USDA Agricultural Baseline Projections to 2014 [online], 2005. Baseline Report OCE2005-1, 116 pp. Available at http://www.usda.gov/oce/ waob/commodity-projections/proj.htm. Accessed 17 March 2005.

29 Beef Promotion and Research Board. Beef demand climbs nearly eight percent in 2004 [online], 2005. Available at www.beefboard.org. Accessed 16 February 2005.

30 Economic Research Service, US Department of Agriculture. Livestock, Dairy, and Poultry Outlook [online], November and December 2004. Available at http://www.ers.usda.gov/ publications/1dp/. Accessed 27 April 2005.

31 American Heart Association. An Eating Plan for Healthy Americans [online], 2005. Available at http://www. americanheart.org/presenter.jhtml?identifier $=1088$. Accessed 5 January 2005.

32 United Nations Food and Agriculture Organization. FAOSTAT Database [online], 2004. Available at http://www. faostat.fao.org/faostat/collections? subset = agriculture. Accessed 8 January 2004.

33 Horrigan L, Lawrence RS, Walker P. How sustainable agriculture can address the environmental and human health harms of industrial agriculture. Environmental Health Perspectives 2002; 110(5): 445-56.

34 Caballero B, Popkin BM. The Nutrition Transition: Diet and Disease in the Developing World. San Diego, CA: Academic Press, 2002

35 World Health Organization (WHO). Diet, Nutrition, and the Prevention of Chronic Disease. WHO Technical Report Series No. 913. Geneva: WHO, 2003.

36 Kitalyi AJ. Village Chicken Production Systems in Rural Africa: Housebold Food Security and Gender Issues. Rome: Food and Agricultural Organization of the United Nations, 1998.

37 Pimentel D, Berger B, Filiberto D, Newton M, Wolfe B, Karabinakis $\mathrm{E}$, et al. Water resources: agricultural and environmental issues. BioScience 2004; 54(10): 909-18.

38 Aron JL, Patz J. Ecosystem Change and Public Health: A Global Perspective. Baltimore, MD: Johns Hopkins University Press, 2001.

39 Stockholm International Water Institute (SIWI) and International Water Management Institute. Water - More Nutrition per Drop. Towards Sustainable Food Production and Consumption Patterns in a Rapidly Changing World. Stockholm: SIWI, 2004.

40 Cook M. Reducing water pollution from animal feeding operations. Testimony before Subcommittee on Forestry, Resource Conservation, and Research of the Committee on Agriculture, US House of Representatives, 13 May 1998. Available at http://www.epa.gov/ocirpage/hearings/ testimony/105_1997_1998/051398.htm. Accessed 17 March 2005.

41 Food and Nutrition Board, Institute of Medicine. Dioxins and Dioxin-like Compounds in the Food Supply: Strategies to Decrease Exposure. Washington, DC: National Academies Press, 2003

42 Brown LR. Who Will Feed China? Wake-up Call for a Small Planet, 1st ed. New York: WW Norton, 1995.

43 Brown LR. Running on empty. Forum for Applied Research and Public Policy 2001; 16(1): 6-8.

44 Black KD. Environmental Impacts of Aquaculture. Sheffield: Sheffield Academic, 2001.

45 Gewin V. Troubled waters: the future of global fisheries. PLoS Biology 2004; 2(4): E113 Available at http://biology. plosjournals.org/perlserv/?request $=$ index-html\&issn $=1545-$ 7885 .

46 Clarkson TW, Strain JJ. Nutritional factors may modify the toxic action of methyl mercury in fish-eating populations. Journal of Nutrition 2003; 133(Suppl. 1): 1539S-43S.

47 Stokstad E. Salmon survey stokes debate about farmed fish. Science 2004; 303(5655): 154-5.

48 US Environmental Protection Agency. Regulatory Definitions of Large CAFOs, Medium CAFOs, and Small CAFOs [online], 2004. Available at http://www.epa.gov/npdes/ pubs/sector_table.pdf. Accessed 8 January 2005.

49 Osterberg D, Wallinga D. Addressing externalities from swine production to reduce public health and environmental impacts. American Journal of Public Health 2004; 94(10): 1703-8.

50 American Public Health Association. Resolution 2003-7, Precautionary Moratorium on New Concentrated Animal Feed Operations [online], 2004. Available at http:// www.apha.org/legislative/policy/policysearch/index.cfm? fuseaction $=$ view\&id $=1243$. Accessed 25 October 2004 . 
51 Fleming R, Ford M. Humans versus Animals - Comparison of Waste Properties [online], 2004. Available at http://www. gov.on.ca/OMAFRA/english/crops/field/news/croptalk/ 2001/ct_1101a9.htm. Accessed 14 December 2004.

52 Wing S, Wolf S. Intensive livestock operations, health, and quality of life among eastern North Carolina residents. Environmental Health Perspectives 2000; 108(3): 233-8.

53 Hamscher G, Pawelzick HT, Sczesny S, Nau H, Hartung J. Antibiotics in dust originating from a pig-fattening farm: a new source of health hazard for farmers? Environmental Health Perspectives 2003; 111(13): 1590-4.

54 Wing S, Freedman S, Band L. The potential impact of flooding on confined animal feeding operations in eastern North Carolina. Environmental Health Perspectives 2002; 110(4): 387-91.

55 Arai Y, Lanzirotti A, Sutton S, Davis JA, Sparks DL. Arsenic speciation and reactivity in poultry litter. Environmental Science \& Technology 2003; 37(18): 4083-90.

56 Lasky T, Sun W, Kadry A, Hoffman MK. Mean total arsenic concentrations in chicken 1989-2000 and estimated exposures for consumers of chicken. Environmental Health Perspectives 2004; 112(1): 18-21.

57 Silbergeld EK. Arsenic in food. Environmental Health Perspectives 2004; 112(6): A338-9.

58 Flora JL, Hodne CJ, Goudy W, Osterberg D, Kliebenstein J, Thu KM, et al. Social and community impacts. In: Iowa State University and University of Iowa Study Group, ed. Iowa Concentrated Animal Feeding Operations Air Quality Study. Iowa City Ames, IA: Iowa State University The University of Iowa Study Group, 2002; 147-63.

59 Mellon M, Benbrook C, Benbrook KL. Hogging It: Estimates of Antimicrobial Abuse in Livestock, 1st ed. Cambridge, MA: Union of Concerned Scientists, 2001.

60 Chee-Sanford JC, Aminov RI, Krapac IJ, Garrigues-Jeanjean $\mathrm{N}$, Mackie RI. Occurrence and diversity of tetracycline resistance genes in lagoons and groundwater underlying two swine production facilities. Applied and Environmental Microbiology 2001; 67(4): 1494-502.

61 World Health Organization (WHO). Antibiotic use in foodproducing animals must be curtailed to prevent increased resistance in humans. Press Release WHO/73. Geneva: WHO, 1997

62 American Public Health Association. Resolution 2004-13, Helping Preserve Antibiotic Effectiveness by Stimulating Demand for Meats Produced Without Excessive Antibiotics [online], 2004. Available at http://www.apha.org/legislative/ policy/policysearch/index.cfm?fuseaction $=$ view\&id $=1299$. Accessed 6 January 2005.
63 American Academy of Microbiology. Antimicrobial Resistance: An Ecological Perspective. Washington, DC: American Academy of Microbiology, 1999; 1-14.

64 Schiffman SS, Bennett JL, Raymer JH. Quantification of odors and odorants from swine operations in North Carolina. Agricultural and Forest Meteorology 2001; 108: 213-40.

65 Chapin A, Rule A, Gibson K, Buckley T, Schwab K. Airborne multidrug-resistant bacteria isolated from a concentrated swine feeding operation. Environmental Health Perspectives 2005; 113(2): 137-42.

66 Cole D, Todd L, Wing S. Concentrated swine feeding operations and public health: a review of occupational and community health effects. Environmental Health Perspectives 2000; 108(8): 685-99.

67 Merchant JA, Naleway AL, Svendsen ER, Kelly KM, Burmeister LF, Stromquist AM, et al. Asthma and farm exposures in a cohort of rural Iowa children. Environmental Health Perspectives 2005; 113(3): 350-6.

68 Striffler $S$. Inside a poultry processing plant: an ethnographic portrait. Labor History 2002; 43(3): 305-13.

69 Green JJ, Barham E. Globalization and Latino Labor: Labor Advocates' Accounts of Meatpacking in Rural Missouri. Latinos in Missouri Occasional Paper series, No. 1. Columbia, Mo: University of Missouri, Department of Rural Sociology, 2002; 1-14.

70 Stull DD, Broadway MJ. Slaughterhouse Blues: The Meat and Poultry Industry in North America. Belmont, CA: Thomson/Wadsworth, 2004.

71 Thu K, Donham K, Ziegenhorn R, Reynolds S, Thorne P, Subramanian $\mathrm{P}$, et al. A control study of the physical and mental health of residents living near a large-scale swine operation. Journal of Agricultural Safety and Health 1997; 3(1): 13-26.

72 Branfman F. Living in shimmering disequilibrium [online], 2000. Available at http://dir.salon.com/people/ feature/2000/04/22/eowilson/index.html. Accessed 17 March 2005.

73 Food and Agriculture Organization of the United Nations (FAO). Rome Declaration on Food Security. World Food Summit, 13-16 November 1996. Rome: FAO, 1997.

74 US Department of Health and Human Services, US Department of Agriculture. Dietary Guidelines for Americans 2005 [online], 2005. Available at http://www. healthierus.gov/dietaryguidelines/. Accessed 12 February 2005.

75 Berry W. Sex, Economy, Freedom \& Community: Eight Essays, 1st ed. New York: Pantheon Books, 1993. 